\title{
Physicochemical, Microstructural and Sensory Impact of Fat Replacers on Low-fat Edam Cheese Manufactured from Buffalo's Milk
}

\author{
Safaa A. M. El-Aidie ${ }^{1 *}$, Ebtisam I. Ghita ${ }^{2}$, Samia M. El-Dieb ${ }^{3}$, Hosam-Eddin M. El-Garhi ${ }^{4}$ \\ ${ }^{1}$ Assistant Professor, Department of Dairy Technology Research, Animal Production Research Institute, \\ Agricultural Research Center, Giza, Egypt \\ ${ }^{2,3}$ Professor, Department of Dairy Science, Faculty of Agriculture, Cairo University, Giza, Egypt \\ ${ }^{4}$ Assistant Professor, Department of Dairy Science and Technology, Faculty of Agriculture, Fayoum University, \\ Fayoum, Egypt \\ ${ }^{*}$ Correspondence E-mail : gmido55@yahoo.com
}

\begin{abstract}
The objective of the current work was to evaluate the effect of three different commercial proteinbased fat replacers Prolo $\AA_{11}(P R)$, Simplesse ${ }^{\circledR} 100(S M)$ and Dairy $L^{T M}(D L)$ on the physicochemical, microstructural, and sensory characteristics of low-fat Edam cheese (LFEC) made from buffalo's milk during a specific ripening period. LFEC treatments were prepared using different ratios $(0.3 \%, 0.6 \%$, and $0.9 \% \mathrm{w} / \mathrm{w}$ marked I, II and III respectively) for each PR, SM and DL. Cheese without fat replacer was prepared as the control $(C)$. Cheese containing fat replacers had a higher significant moisture content than C. Proteolysis significantly increased in LFEC containing Fat replacers more than C. Firmness decreased gradually with increasing the concentration of the fat replacers. PRIII and SMIII had less firmness. The addition of SM and PR improved texture, flavour and acceptability of the LFEC on the $60^{\text {th }}$ day of ripening. DL treatments achieved the best total scores for sensory characteristics on the $90^{\text {th }}$ day of ripening. Fat replacers affected the microstructure of LFEC especially SM which imparts a desirable texture to cheese, compared to other treatments.
\end{abstract}

Keywords: Physicochemical; Edam cheese; Fat replacers; Microstructure; Sensory characteristics

\section{Introduction}

Edam cheese is one of the most important types of semi-hard cheese originated in the Netherlands and usually made from cows' milk. Edam cheese has a moderately taste, low-salted or nutty, and has almost no odor when compared to other cheeses. (Oliveira et al., 2011).

Recently, modern consumers are more health conscious and attach greater importance to the health benefits and risks of their dietary intake especially with the prevalence of health information (De-Magistris and Lopéz-Galán, 2016; El-Aidie et al., 2017; El-Aidie, 2018a; ElGarhi et al., 2018; McCarthy et al., 2017). The incidences of chronic diseases are associated with excessive fat intake. A reduction in food fat consumption is thus widely recommended (Palatnik et al., 2017; El-Aidie 2018b). In fact, LFC production has significantly increased over the world. Nevertheless, due to the major role of fats in the overall physical characteristics of many foods, the removal of fats often deteriorates the appearance and 
palatability of the finished products (Koca and Metin, 2004). Specifically, LFC frequently suffer from over-firm and elastic texture as well as slowers down the ripening which influences their texture, flavour profile, functional properties, and overall acceptability due to the protein-dominated structure of these products (Diamantino et al., 2014; Junyusen et al., 2017).

Consequently, several attempts have been conducted to overcome the characteristics of cheeses with reduced fat content in terms of texture, functionality, and appearance that include the addition of some ingredients or modifications to the main manufacturing steps (Sandrou and Arvanitoyannis, 2000). Many additions of ingredients have been used, including the addition of adjunct starter culture (Ayyash et al., 2018; Costa et al., 2010; McCarthy et al., 2017), coagulants (Govindasamy-Lucey et al., 2010; Madadlou et al., 2005), stabilizers and fat replacers (Jooyandeh et al., 2017; Kavas et al., 2004; Koca and Metin, 2004; Nateghi et al., 2012; Sahan et al., 2008) and used preacidification (Johnson et al., 2009). Some modification or addition of steps during cheese manufacture have been also used to improve texture which include curd washing or cutting into larger cubes (Lee et al., 2005), high hydrostatic pressure treatment (Sheehan et al. 2005), homogenisation of cheese milk (Karaman and Akalin, 2013), draining and milling at a higher pH (El Soda, 2014) and lowering the cooking temperature (Sheibani et al., 2017).

The use of FR has gained popularity so far since they can be integrated into traditional food products, as in cheese, to give similar functions as in the full-fat analog. They are classified as fat mimetics which are proteinand carbohydrate-based, and fat substitutes which are fat-based. Fat mimetics consist of microparticulated protein and carbohydratebased substances, which are often recommended for low-fat cheese products. (Romeih et al., 2002). These substances are used to improve the sensory and functional properties of LFC by linking water and improving texture and yield (Drake et al., 1996). Therefore, they give a sense of lubricity and creaminess (McMahon et al., 1996).
Several studies tackled fat replacers as a means of improving the structure of various low-fat cheeses such as Cheddar, mozzarella, and white cheeses. The most important fat replacers used are Simpless 100 and Dairy Lo. To our knowledge, no previous studies have used Prolo 11 as a protein-based fat replacer and buffalo milk in the manufacture of low-fat Edam cheese. However, from a literature survey, few studies still exist on the use of fat replacers in commercial cheeses such as Edam cheese.

Despite the diversity of strategies to improve the characteristics of LFC, fat replacers are still the most effective ones. Therefore, the purpose of the study is to assess the effect of three different fat replacers Prolo $\AA 11$, Simplesse ${ }^{\circledR} 100$ and Dairy Lo $^{T M}$ on the physiochemical, microstructural, and sensory characteristics of LFEC).

\section{Materials and Methods}

\section{Materials}

Raw buffalo's milk was purchased from the Faculty of Agriculture, Cairo University, Egypt. Protein-based fat replacers were Simplesse $\AA_{100}$ (Nutra Sweet Kelco CO., San Diego, CA. which is the microparticulated whey protein), Dairy $\mathrm{LO}^{\mathrm{TM}}$ (Cultor Food Science, Ardsley, NY), denatured whey proteins and Prolo $\AA 11 \quad((3886 \mathrm{C})$ kerry Ingredients, Beloit, WI) denatured whey proteins and stabilizers. Starter cultures (Mesophilic Aromatic Culture with produces CO2 type, LD-culture $\mathrm{CH}-\mathrm{N} 22$ multiple mixed strain culture) including Lactococcus lactis subsp. cremoris, Lactococcus lactis subsp. Lactis, Leuconostoc mesenteroides subsp. cremoris and Lactococcus lactis subsp. Lactis biovar diacetyltactis, were obtained from $\mathrm{CHR}$ Hansen, Denmark. Anatto colour (Milwaukee Wisconsin Pfizer). Liquid calf rennet (rich in chymosin) and salt were purchased from local market.

\section{Methods}

\section{Cheese Manufacture}

LFEC treatments were prepared with different ratios $(0.3 \%, 0.6 \%$, and $0.9 \% \mathrm{w} / \mathrm{w}$ signed $\mathrm{I}$, II 
and III respectively) for each PR, SM and DL. control cheese without fat replacer was also prepared, for comparison. The fat content of milk was standardized to $1.5 \%$ for low-fat cheese preparation. $30 \mathrm{~kg}$ of standardized milk were used for each batch. The FR were added to the cheese milk at $30^{\circ} \mathrm{C}$ and mixed for 5 min. Then, all batches were pasteurized at $72^{\circ} \mathrm{C}$ for $15-30 \mathrm{sec}$ and then cooled to $30^{\circ} \mathrm{C}$. The starter culture $(1 \% \mathrm{w} / \mathrm{w})$, Anatto colour $(160 \mu \mathrm{L})$ and $0.02 \%$ Calcium chloride (food grade) were added and the milk was held for 20-30 min. Liquid calf rennet $(25 \mathrm{~mL}$ of $1 \mathrm{~N}$ rennet to $100 \mathrm{~L}-1$ of milk, 45 min coagulation) was added to coagulate the milk by keeping the temperature of incubation at $30^{\circ} \mathrm{C}$. The curd was cut into $1 \mathrm{~cm} 3$ cubes and rested for $20 \mathrm{~min}$. The temperature of the curd was raised to $38^{\circ} \mathrm{C}$ by the addition of $1 \mathrm{~L}$ sterile distilled water at $65^{\circ} \mathrm{C}$ (cooking step). Cheese curd was pressed in moulds covered with cheese cloth at $10-15 \mathrm{~kg} / \mathrm{cm} 2$ for $3 \mathrm{hrs}$. The cheese was turned and re-pressed overnight and the temperature of the curd was maintained at $15-20^{\circ} \mathrm{C}$. The curd was immersed in a brine solution with $20 \% \mathrm{w} / \mathrm{v}$ $\mathrm{NaCl}$ for $20 \mathrm{hr}$, at $10 \pm 1^{\circ} \mathrm{C}$. The Cheeses were allowed to form a rind and then coated with wax. The obtained cheese was finally stored at $10 \pm 1^{\circ} \mathrm{C}$ and $100 \%$ relative humidity. Cheese treatments were removed from the refrigerator $1 \mathrm{~h}$ before measurement to reach the temperature of room degree. Cheese samples were analyzed for chemical, textural, microstructure and sensory evaluation at different ripening periods $(1,30,60$ and 90 days). All cheese analyses were performed three times.

\section{Cheese Physicochemical Analysis}

The cheese samples were analyzed for acidity, moisture content and ash content according to (AOAC, 2000), $\mathrm{pH}$ values were estimated by a Microprocessor $\mathrm{pH}$ meter (Hanna Instruments Ltd., Bedfordshire, UK) after mixing $20 \mathrm{~g}$ of a grated cheese sample with $12 \mathrm{~mL}$ of distilled water. Fat content was determined by Gerber method (Marshal, 1993). Protein content was measured by Kjeldhal method (IDF, 2006). Finally, salt content was measured using the potentiometric method (Fox, 1963).

\section{Proteolysis Assessment}

Proteolysis was assessed by determining the levels of water-soluble nitrogen (WSN) according to the method of Kuchroo and Fox, (1982). Nitrogen content was assessed by the Kjeldahl method (IDF, 2006) and results were expressed as a percentage of total nitrogen (TN\%).

\section{Firmness Analysis}

Textural characteristics of Edam cheese were analyzed at 30,60 and 90 days of ripening for firmness. The cone penetrometer (Stanhope Seta, Surrey, United Kingdom) was used for measuring the firmness of cheese at $15^{\circ} \mathrm{C}$. The penetrometer was equipped with two different weights, $47.5 \mathrm{~g}$ as a standardized rod weight and $35 \mathrm{~g}$ as an additional weight (Total $82.5 \mathrm{~g}$ ). The whole scale was calibrated in 35 units; furthermore, each unit was divided into 10 parts, $0.1 \mathrm{~mm}$ each. For measurement, the cheese sample was put on the base and the penis moves down until the tip of the cone just rests on the cheese. Then the cone which releases the button was depressed $5 \mathrm{sec}$., for recording distance in units of $0.1 \mathrm{~mm}$. The measurement was repeated four times using four different locations on the surface of a cheese sample and the penetration value was recorded as the average of all these penetration depths (in $\mathrm{mm}$ ).

\section{Scanning Electron Microscope (SEM)}

The network structure of $0.9 \% \mathrm{SM}, 0.9 \% \mathrm{PR}$ samples after 2 months and $0.9 \% \mathrm{DL}$ after 3 months of ripening was studied by scanning electron microscopy (SEM). Cheese samples were prepared using the thin-sectioning technique for preparation according to Søndergaard et al., (2015). Small pieces (1 $\mathrm{mm} 3$ each) of cheese were prefixed for $2 \mathrm{hr}$ in a $2 \%$ glutaraldehyde solution ( $\mathrm{pH}$ 6.8) buffered with sodium cacodylate, followed by a postifixation for $2 \mathrm{hr}$ in a mixture of osmium textroxide and $2 \%$ tannic acid at $\mathrm{pH} 6.0$ (cacodylate buffer). The fixed samples were dehydrated step wise in ethanol, and then transferred into acetone. Samples were dried by Balzer sunion in critical point dryer and coated with thin film of gold. The samples 
were investigated by scanning microscope (Jeol JSM-T20).

\section{Sensory properties}

The sensory evaluation was conducted with the points scoring test by the 10 panellists of the committee who are members of the Research Division, Lincoln University College and Dairy Science and technology Department, Faculty of Agriculture, Fayoum University. The samples were tested in a uniformly illuminated chamber, to evaluate the effect of fat reduction and the addition of fat replacers on sensory parameters according to Clark et al. (2009).

\section{Statistical Analysis}

All data obtained were subjected to the statistical analysis that was performed by the SPSS version 19.0 (SPSS 1999, Statistical Package for Social Sciences, SPSS Inc., 444, North Michigan Avenue, Chicago, IL 606 11, USA), and Sigma plot 12.0 software programs.

\section{Results and Discussions}

\section{Physicochemical analysis}

Using FR in the manufacture of Edam cheese significantly influenced gross composition during ripening (Table 1). Also, as illustrated in Table 1, cheese made with FR contained higher moisture and TN/DM content than $C$ cheese and this increase was proportional to the ratio of added FR. These observations are in agreement with the data reported by several authors for various cheeses, (Romeih et al., 2002; Kavas et al., 2004; Sahan et al., 2008). The highest moisture contents were observed in PR and SM cheeses as it was $53.11 \%$ and 52.07 at $0.9 \%$ concentration compared to the DL cheese as it was $51.73 \%$ at the same concentration. These results were consistent partly with those reported by McMahon et al., (1996), who found that Simplesse appeared as fine particles embedded in the casein network, which allowed greater moisture retention. The results also show a continuous decrease in moisture content of all cheese samples as the ripening period progressed to reach minimum values after 90 days. This may be due to the evaporation occurring in the cheese during the ripening period. These results were in agreement with the findings of Kumar and Upadhyay, (1998). Also, results show TN/DM value of $D L$ cheese was significantly higher than that of SM and PR cheeses. A similar observation has been obtained by Drake et al., (1996).

The F/DM content of cheese fell in the range of $4.61-5.4 \%$ with statistically non-significant differences. Salt-in-moisture (S/M) of SM, DL and PR cheeses at $0.9 \%$ had lower significant levels than the other cheeses, probably due to their higher moisture content. Similar results have been obtained for the current study by Romeih et al., (2002).

\section{Titratable acidity and pH}

It is obviously clear from Figure. 1 that using FR had no significant impact on the $\mathrm{pH}$ and titratable acidity (TA) in all treatments compared to $C$ when fresh. TA of all cheese samples had the same trend, as it dramatically increased during ripening period to reach higher values after 60 days, then gradually decreased until the end of ripening period. This may be due to the lower moisture content and higher salt content of cheese samples at the end of ripening that would inhibit the growth of cheese microflora. These results were in agreement with those conducted by Katsiari and Voutsinas, (1994).

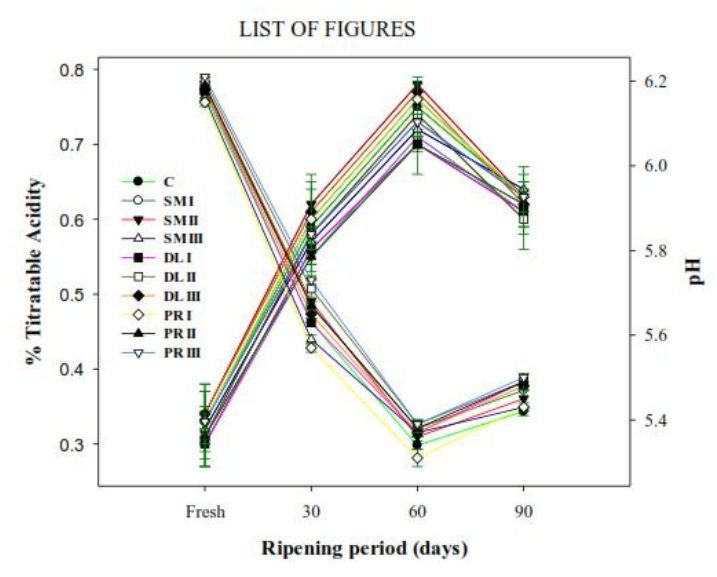

Figure 1. Effect of using fat replacers on titratable acidity and $\mathrm{pH}$ of low-fat buffaloes' Edam cheese during ripening. 
Table 1. Physicochemical composition of low-fat Edam cheese made from buffalo milk using fat replacers during storage periods.

\begin{tabular}{|c|c|c|c|c|c|}
\hline Treatments & $\begin{array}{l}\text { Ripening period } \\
\text { (days) }\end{array}$ & Moisture\% & TN/DM\% & Fat/DM\% & Salt/M \% \\
\hline C & $\begin{array}{c}\text { Fresh } \\
30 \\
60 \\
90\end{array}$ & $\begin{array}{c}49.32 \pm 0.30^{\mathrm{abc}} \\
48.13 \pm 0.32^{\mathrm{abc}} \\
47.66 \pm 0.71^{\mathrm{abc}} \\
47.03 \pm 0.54^{\mathrm{c}}\end{array}$ & $\begin{array}{l}9.20 \pm 0.12^{\mathrm{ab}} \\
9.20 \pm 0.16^{\mathrm{ab}} \\
9.20 \pm 0.09^{\mathrm{ab}} \\
9.19 \pm 0.20^{\mathrm{b}}\end{array}$ & $\begin{array}{l}25.25 \pm 0.04^{\mathrm{a}} \\
25.25 \pm 0.12^{\mathrm{a}} \\
25.21 \pm 0.06^{\mathrm{a}} \\
25.29 \pm 0.32^{\mathrm{a}}\end{array}$ & $\begin{array}{c}4.64 \pm 0.45^{\text {def }} \\
4.79 \pm 0.64^{\text {cdef }} \\
4.93 \pm 0.34^{\text {bc }} \\
5.10 \pm 0.39^{\mathrm{b}}\end{array}$ \\
\hline SM I & $\begin{array}{l}\text { Fresh } \\
30 \\
60 \\
90\end{array}$ & $\begin{array}{l}50.31 \pm 0.24^{\mathrm{ab}} \\
49.62 \pm 0.28^{\mathrm{abc}} \\
49.05 \pm 0.54^{\mathrm{abc}} \\
48.59 \pm 0.34^{\mathrm{abc}}\end{array}$ & $\begin{array}{l}9.22 \pm 0.14^{\mathrm{ab}} \\
9.22 \pm 0.21^{\mathrm{ab}} \\
9.21 \pm 0.19^{\mathrm{ab}} \\
9.21 \pm 0.10^{\mathrm{ab}}\end{array}$ & $\begin{array}{l}25.35 \pm 0.36^{a} \\
25.20 \pm 0.17^{\mathrm{a}} \\
25.31 \pm 0.43^{\mathrm{a}} \\
25.25 \pm 0.21^{\mathrm{a}}\end{array}$ & $\begin{array}{c}4.69 \pm 0.62^{\text {def }} \\
4.81 \pm 0.54^{\text {cde }} \\
4.97 \pm 0.43^{\mathrm{bc}} \\
5.12 \pm 0.38^{\mathrm{ab}}\end{array}$ \\
\hline SM II & $\begin{array}{l}\text { Fresh } \\
30 \\
60 \\
90\end{array}$ & $\begin{array}{l}50.98 \pm 0.72^{\mathrm{ab}} \\
49.91 \pm 0.65^{\mathrm{abc}} \\
49.36 \pm 0.44^{\mathrm{abc}} \\
48.92 \pm 0.48^{\mathrm{abc}}\end{array}$ & $\begin{array}{l}9.22 \pm 0.08^{\mathrm{ab}} \\
9.21 \pm 0.11^{\mathrm{ab}} \\
9.22 \pm 0.09^{\mathrm{ab}} \\
9.22 \pm 0.16^{\mathrm{ab}}\end{array}$ & $\begin{array}{l}25.49 \pm 0.02^{\mathrm{a}} \\
25.55 \pm 0.07^{\mathrm{a}} \\
25.47 \pm 0.18^{\mathrm{a}} \\
25.47 \pm 0.23^{\mathrm{a}}\end{array}$ & $\begin{array}{c}4.84 \pm 0.12^{\text {cde }} \\
4.97 \pm 0.71^{\text {bc }} \\
5.08 \pm 0.66^{\mathrm{b}} \\
5.23 \pm 0.34^{\mathrm{a}}\end{array}$ \\
\hline SMIII & $\begin{array}{l}\text { Fresh } \\
30 \\
60 \\
90\end{array}$ & $\begin{array}{l}52.07 \pm 0.85^{\mathrm{a}} \\
51.28 \pm 0.64^{\mathrm{ab}} \\
50.62 \pm 0.76^{\mathrm{ab}} \\
49.99 \pm 0.43^{\mathrm{ab}}\end{array}$ & $\begin{array}{l}9.23 \pm 0.22^{\mathrm{ab}} \\
9.22 \pm 0.15^{\mathrm{ab}} \\
9.23 \pm 0.18^{\mathrm{ab}} \\
9.23 \pm 0.14^{\mathrm{ab}}\end{array}$ & $\begin{array}{l}25.66 \pm 0.22^{\mathrm{a}} \\
25.86 \pm 0.12^{\mathrm{a}} \\
25.71 \pm 0.09^{\mathrm{a}} \\
25.79 \pm 0.40^{\mathrm{a}}\end{array}$ & $\begin{array}{c}4.82 \pm 0.73^{\text {cde }} \\
4.91 \pm 0.40^{\mathrm{c}} \\
5.09 \pm-.35^{\mathrm{b}} \\
5.24 \pm 0.23^{\mathrm{a}}\end{array}$ \\
\hline DL I & $\begin{array}{l}\text { Fresh } \\
30 \\
60 \\
90\end{array}$ & $\begin{array}{l}49.87 \pm 0.66^{\mathrm{abc}} \\
49.13 \pm 0.70^{\mathrm{abc}} \\
48.83 \pm 0.21^{\mathrm{abc}} \\
48.32 \pm 0.90^{\mathrm{abc}}\end{array}$ & $\begin{array}{l}9.22 \pm 0.13^{\mathrm{ab}} \\
9.23 \pm 0.20^{\mathrm{ab}} \\
9.22 \pm 0.18^{\mathrm{ab}} \\
9.22 \pm 0.10^{\mathrm{ab}}\end{array}$ & $\begin{array}{l}25.33 \pm 0.12^{\mathrm{a}} \\
25.35 \pm 0.24^{\mathrm{a}} \\
25.40 \pm 0.03^{\mathrm{a}} \\
25.34 \pm 0.06^{\mathrm{a}}\end{array}$ & $\begin{array}{c}4.61 \pm 0.54^{\text {def }} \\
4.70 \pm 0.65^{\text {def }} \\
4.79 \pm 0.23^{\text {cdef }} \\
4.90 \pm 0.42^{\text {bc }}\end{array}$ \\
\hline DL II & $\begin{array}{l}\text { Fresh } \\
30 \\
60 \\
90\end{array}$ & $\begin{array}{l}50.26 \pm 0.32^{\mathrm{ab}} \\
49.38 \pm 0.44^{\mathrm{abc}} \\
48.97 \pm 0.52^{\mathrm{abc}} \\
48.61 \pm 0.46^{\mathrm{abc}}\end{array}$ & $\begin{array}{l}9.28 \pm 0.19^{\mathrm{a}} \\
9.26 \pm 0.21^{\mathrm{a}} \\
9.27 \pm 0.10^{\mathrm{a}} \\
9.28 \pm 0.15^{\mathrm{a}}\end{array}$ & $\begin{array}{l}25.33 \pm 0.33^{\mathrm{a}} \\
25.28 \pm 0.11^{\mathrm{a}} \\
25.27 \pm 0.01^{\mathrm{a}} \\
25.29 \pm 0.32^{\mathrm{a}}\end{array}$ & $\begin{array}{c}4.59 \pm 0.22^{\text {def }} \\
4.72 \pm 0.12^{\text {def }} \\
4.79 \pm 0.43^{\text {cdef }} \\
4.93 \pm 0.33^{\text {bc }}\end{array}$ \\
\hline DL III & $\begin{array}{l}\text { Fresh } \\
30 \\
60 \\
90\end{array}$ & $\begin{array}{l}51.73 \pm 0.66^{\mathrm{ab}} \\
50.84 \pm 0.82^{\mathrm{ab}} \\
50.36 \pm 0.90^{\mathrm{ab}} \\
49.67 \pm 0.74^{\mathrm{abc}}\end{array}$ & $\begin{array}{l}9.29 \pm 0.11^{\mathrm{a}} \\
9.23 \pm 0.17^{\mathrm{ab}} \\
9.30 \pm 0.21^{\mathrm{a}} \\
9.29 \pm 0.13^{\mathrm{a}}\end{array}$ & $\begin{array}{l}25.68 \pm 0.19^{a} \\
25.63 \pm 0.22^{a} \\
25.58 \pm 0.32^{a} \\
25.63 \pm 0.19^{a}\end{array}$ & $\begin{array}{c}4.52 \pm 0.20^{f} \\
4.66 \pm 0.60^{\text {def }} \\
4.76 \pm 0.43^{\text {cdef }} \\
4.89 \pm 0.36^{\mathrm{cd}}\end{array}$ \\
\hline PR I & $\begin{array}{l}\text { Fresh } \\
30 \\
60 \\
90\end{array}$ & $\begin{array}{l}50.92 \pm 0.44^{\mathrm{ab}} \\
50.31 \pm 0.53^{\mathrm{ab}} \\
49.99 \pm 0.58^{\mathrm{ab}} \\
49.36 \pm 0.92^{\mathrm{abc}}\end{array}$ & $\begin{array}{l}9.22 \pm 0.16^{\mathrm{ab}} \\
9.23 \pm 0.23^{\mathrm{ab}} \\
9.24 \pm 0.12^{\mathrm{ab}} \\
9.22 \pm 0.09^{\mathrm{ab}}\end{array}$ & $\begin{array}{l}25.67 \pm 0.24^{\mathrm{a}} \\
25.55 \pm 0.14^{\mathrm{a}} \\
25.59 \pm 0.27^{\mathrm{a}} \\
25.47 \pm 0.09^{\mathrm{a}}\end{array}$ & $\begin{array}{c}4.75 \pm 0.15^{\text {cdef }} \\
4.91 \pm 0.45^{\mathrm{c}} \\
4.98 \pm 0.33^{\mathrm{bc}} \\
5.12 \pm 0.20^{\mathrm{ab}}\end{array}$ \\
\hline PR II & $\begin{array}{c}\text { Fresh } \\
30 \\
60 \\
90\end{array}$ & $\begin{array}{l}50.88 \pm 1.00^{\mathrm{ab}} \\
51.17 \pm 0.68^{\mathrm{ab}} \\
50.62 \pm 0.78^{\mathrm{ab}} \\
50.21 \pm 0.34^{\mathrm{ab}}\end{array}$ & $\begin{array}{l}9.24 \pm 0.17^{\mathrm{ab}} \\
9.25 \pm 0.13^{\mathrm{a}} \\
9.24 \pm 0.21^{\mathrm{ab}} \\
9.25 \pm 0.10^{\mathrm{a}}\end{array}$ & $\begin{array}{l}25.76 \pm 0.04^{\mathrm{a}} \\
25.80 \pm 0.15^{\mathrm{a}} \\
25.71 \pm 0.17^{\mathrm{a}} \\
25.70 \pm 0.10^{\mathrm{a}}\end{array}$ & $\begin{array}{c}4.84 \pm 0.19^{\text {cde }} \\
4.98 \pm 0.43^{\mathrm{bc}} \\
5.07 \pm 0.29^{\mathrm{b}} \\
5.22 \pm 0.24^{\mathrm{a}}\end{array}$ \\
\hline PR III & $\begin{array}{l}\text { Fresh } \\
30 \\
60 \\
90\end{array}$ & $\begin{array}{l}53.11 \pm 0.66^{\mathrm{a}} \\
52.31 \pm 0.61^{\mathrm{a}} \\
51.97 \pm 0.75^{\mathrm{ab}} \\
51.33 \pm 0.82^{\mathrm{ab}}\end{array}$ & $\begin{array}{l}9.26 \pm 0.15^{\mathrm{a}} \\
9.25 \pm 0.13^{\mathrm{a}} \\
9.25 \pm 0.11^{\mathrm{a}} \\
9.26 \pm 0.20^{\mathrm{a}}\end{array}$ & $\begin{array}{l}25.59 \pm 0.32^{\mathrm{a}} \\
25.58 \pm 0.06^{\mathrm{a}} \\
25.60 \pm 0.19^{\mathrm{a}} \\
25.68 \pm 0.23^{\mathrm{a}}\end{array}$ & $\begin{array}{c}4.76 \pm 0.15^{\text {cdef }} \\
4.87 \pm 0.32^{\mathrm{cd}} \\
4.92 \pm 0.45^{\mathrm{bc}} \\
5.12 \pm 0.34^{\mathrm{ab}}\end{array}$ \\
\hline
\end{tabular}

Note: Mean $\pm($ St. Dev.) having different alphabets within each column are significantly different $(p \leq$ 0.05). All analyses were done in triplicate. $C=$ Control Low Fat Buffaloes' Edam cheese without fat replacers; $\mathrm{SM}=$ : Simplesse DL= Dairy Lo; $\mathrm{PR}=$ : Prolo. I = 0.3\%; II = 0.6\%; III=0.9\%.

\section{Proteolysis assessment}

The levels of SN/TN were determined during the ripening period (Figure. 2) to monitor the rate and extent of protein degradation in the cheeses. Compared to $\mathrm{C}$, as illustrated in Figure. 2 SN/TN values of cheeses were significantly $(P<0.05)$ affected by adding $F R$ to the cheese milk, reflecting a higher proteolysis rate in all treatments. As the ripening period advanced, SN/TN of all treatments gradually increased $(P<0.05)$. There is no significance between all treatments throughout the first 60 days of ripening period. Whereas, the highest values were significantly noticed in the PR I, PR II and PR III treatments at 90 day of 
ripening period compared to the other treatments as clearly shown in Figure 2.

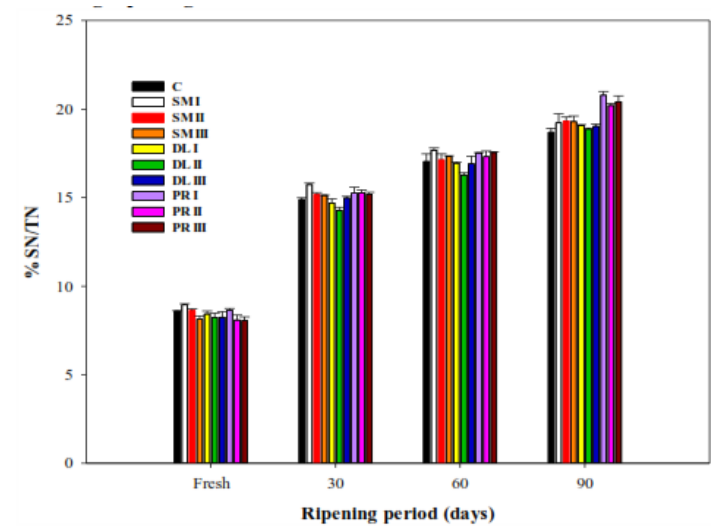

Figure 2. Effect of using fat replacers on SN/TN content of low-fat buffaloes' Edam cheese during ripening.

The higher SN in cheeses made with PR may be attributed to excessive protein breakdown occurring through the growth of cheese microflora and the proteolytic enzyme activity that eventually associate with extra moisture retained by fat replacers. Our results were in agreement with those of Romeih et al., (2002) who reported higher $\mathrm{SN}$ in white-brined cheese made with FR.

\section{Firmness Analysis}

It is noteworthy that, penetrometer readings had an adverse trend to the cheese firmness. As shown in Figure. 3 Cheeses made using FR had a low significant effect on the firmness, where the fresh $C$ treatment was the firmest compared to the other treatments. Firmness of the treated cheeses was affected by both the type and level of the used fat replacers. However, DL cheese had higher firmness, and PR \& SM cheeses showed the opposite trend. These results coincided with those reported by(Koca and Metin, 2004). Also, it is clear from Figure. 3 that the reduction in firmness was most noticed in PR and SM with $0.9 \%$. This decrease might be owing to variation in protein matrix compactness since SM and PR also increase the water binding capacity of protein matrix (Nateghi et al., 2012). The firmness decreased significantly $(P<0.05)$ for all cheeses as the ripening period progressed. However, the different cheese treatments had lower firmness than $\mathrm{C}$ cheese; this finding was in accordance with their corresponding

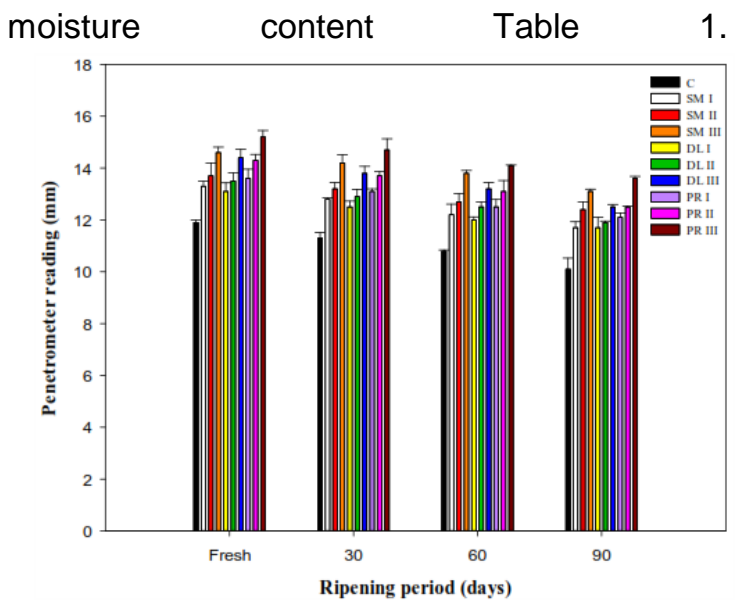

Figure 3. Peneterometer reading $(\mathrm{mm})$ of lowfat buffaloes' Edam cheese as affected by using fat replacers during ripening.

These findings are in agreement with Murtaza et al., (2014), who found the same results in Cheddar cheese texture during ripening. Akkerman et al., 2017 reported that the firmness is a directly related to the proteolysis, i.e., the firmness of the cheeses decreased with increasing proteolysis during ripening. Overall, reduced fat in cheese milk generally resulted in significantly $(P<0.05)$ firmer cheese compared to SM, DL and PR, regardless of ripening time.

\section{Scanning electron microscope (SEM)}

The electron micrographs were taken to prove the relationships between the microstructure of cheeses and their texture. Figure. 4 shows the SEM micrographs obtained for the $C$ cheese at zero, 90 days, SM \& PR cheeses at 90 days and $\mathrm{DL}$ cheese at 60 days of ripening. In all samples, protein matrixes with small little numbers of dispersed fat globules were observed, similar to previous reports (Karaman and Akalin, 2013). This type of structure is common for cheeses made from low fat milk. In this regard, Palatnik et al., (2017) obtained similar images for soft cheeses with small fat globules. Figure. 4A\&B shows low fat cheese when fresh and after ripening. There were differences between the structures of both LFC, where fresh low-fat cheese was compact (Figure. 4A). Also, this cheese had considerably few vacuoles more dense and extensive protein matrix and had a continuous protein matrix interspersed with serum channels, which may explain the hard- 
rubbery body \& texture (Sheibani et al., 2017). These results are in agreement with Mistry and Anderson, (1993). On the contrary, LFC after ripening for 90 days, Fig 4B showed that the individual identity of curd particles in the cheese was invisible as compared to the fresh cheese (Figure 4A), in which the individual identity of curd particles was visible. Also, it can be seen that some of the void space appeared elongated as a result of ripening because of the complete curd fusion owing to the breakdown of casein matrix. These findings were in agreement with Mistry and Anderson, (1993) who mentioned that, after the cheeses had aged, some of the void spaces in cheese appeared elongated. This elongation is considered a typical indication of body development in ripening hard and semihard cheese.

The addition of FR to cheese milk, it had had great effect on the microstructure of low-fat Edam cheese, whereby they altered the cheese protein matrix. The cheese with fat replacers had a more homogeneous microstructure. Figure. 4C shows that addition of $\mathrm{SM}$ at $0.9 \%$ reduced the openness of cheese at the end of ripening. Spherical particles were embedded within the cheese protein matrix and also lying on the fracture surface. This indicated that these layers were formed over a maturation period. Similar observations were reported by Junyusen et al., (2017). The SM particles observed on the fracture surface would originally have been contained in the serum channels, indicating that SM was distributed between the protein matrix and the serum (Soodam et al., 2015). Also, it was noticeable that the SM particles were too small to influence the size of the serum channels and they were the most spherical and were present as particles of a relatively narrow size distribution. The findings were consistent with (Aryana and Haque, 2001) who noted that the addition of Simpless which comprised of microparticulated proteins, into the Cheddar cheese disrupted the formation of protein networks, leading to a more open structural matrix.

Cheese made with $\mathrm{DL}$ and PR at $0.9 \%$ showed presence of larger structures (Figure. 4D\&E) within the matrix, which was not observed in cheese made with SM. These larger structures were the $\mathrm{DL}$ and $\mathrm{PR}$ particles, which had a much lower microparticulation size than SM. From the same Figs. smaller particles were also observed within the protein surface of the serum channels although they were not apparent within the fracture surface. SM was observed as microparticles because it was mostly made by a proprietary process involving high shear, high temperature treatment to generate microparticles as mentioned by (Kucukoner, 1996). It entrenches in the casein matrix that allows major moisture retention than DL or PL, which were presented as fine particles, and led to the higher loss of them from the curd because of its smaller size. On the other hand, any increase in the moisture would be as a result of water-holding abilities of the individual fat replacer particles that were retained in the cheese curd. However, SM, which comprised of microparticulated proteins, gave a discontinuous protein matrix (Figure. 4C), perhaps thus imparting softness to the product. These microstructural observations support the chemical and textural results as the less defined protein matrix structure visualized by the SEM would be expected to result in softer and more compressible cheese texture as observed (Akkerman et al., 2017). 


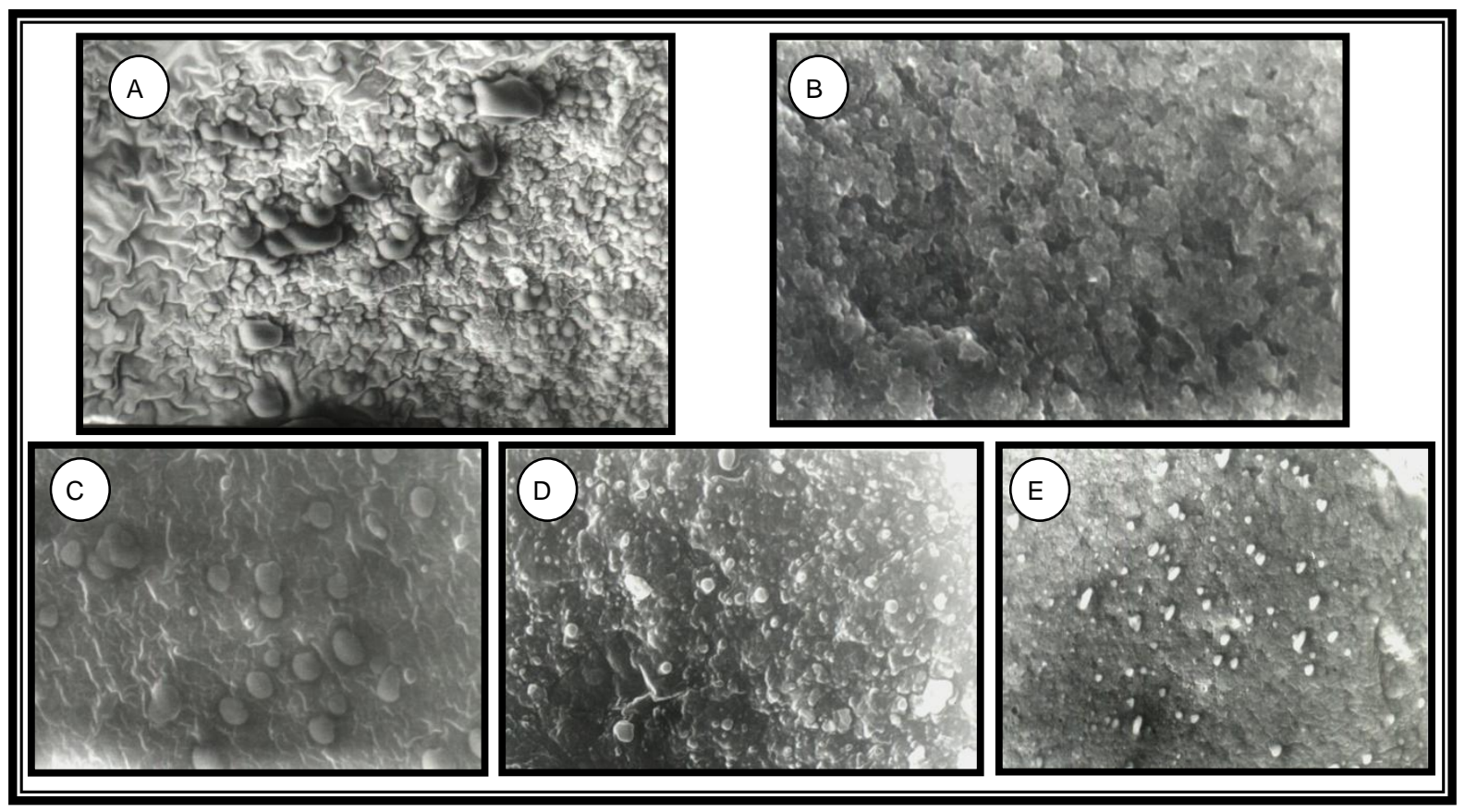

Figure. 4: Scanning electron microscope SEM images of low-fat buffaloes' Edam cheese made with and without fat replacers. A: low fat cheese (LF) when fresh; B: low fat cheese (LF) after 3 months of ripening. Low fat buffaloes' Edam cheese made with fat replacers with C: $0.9 \%$ SM at 60 days of storage; D: $0.9 \%$ PR at 60 days of storage and $\mathbf{E}: 0.9 \% \mathrm{DL}$ at 90 days of storage

\section{Sensory evaluation}

Significant differences were noticed between LFC and cheeses with FR Table 2. The addition of FR results in higher appearance score of low-fat cheese (Murtaza et al., 2017). LFC had a more translucent surface and denser colour than all cheeses with FR. The reason for translucency could be lack of the fat which provides opacity in cheese (Mistry and Anderson, 1993). It could be concluded that using fat replacers corrected all appearance defects which were determined in low-fat fresh Edam cheese. These results are in agreement with Koca and Metin, (2004).

When fresh, FR had a high significant effect on body \& texture scores in treatments compared to control. It is also interesting to note that among all products the PR cheese $(0.9 \%)$ has received higher score followed by DL $(0.9 \%)$ for body \& texture by the judges. These results are in agreement with the findings reported by Romeih et al., (2002) for white-brined cheese. FR had a significant impact on the body \& texture scores of the cheeses during ripening. There was a gradual improvement in body \& texture throughout the ripening period for all cheese samples except treatments SMIII, PRIII which had soggy body that may be due to the high moisture content of these cheeses, while DLIII, DLII, PRII and SMII cheeses had good body \& texture. The difference in body \& texture scores of low-fat Edam cheeses was most likely due to the variation in moisture content of the cheese and continuing proteolysis of the casein matrix (Romeih et al., 2002). The increase in the fat replacer ratio has positive effect on the flavour scores of all samples $(P<0.05)$. Panelists gave significantly higher scores to the PR and DL cheeses at $0.9 \%$ than SM samples. SMIII and PRIII cheeses took higher sensory scores after 2 months than DIII cheese which was more superior in the flavour and gained the highest score after three months of cheese ripening. The most noted defect by the panelists was the bitter taste that appeared in SMIII and PRIII samples at the end of the storage period. Kavas et al., (2004) reported the increase in flavour of cheese made with different fat replacers as compared to LFC. 
Table 2. Effect of fat replacers on sensory evaluation of low-fat Edam cheese made from buffalo milk during storage periods.

\begin{tabular}{|c|c|c|c|c|c|}
\hline Treatments & $\begin{array}{l}\text { Ripening } \\
\text { period } \\
\text { (days) }\end{array}$ & $\begin{array}{l}\text { Flavour } \\
\text { (50 points) }\end{array}$ & $\begin{array}{l}\text { Body and } \\
\text { Texture } \\
\text { (35 points) }\end{array}$ & $\begin{array}{l}\text { Appearance } \\
\text { (15 points) }\end{array}$ & $\begin{array}{l}\text { Total } \\
\text { (100 points) }\end{array}$ \\
\hline C & $\begin{array}{l}\text { Fresh } \\
30 \\
60 \\
90\end{array}$ & $\begin{array}{l}30 \pm 1.00^{i} \\
36 \pm 0.73^{\text {fgh }} \\
39 \pm 0.51^{\text {efg }} \\
42 \pm 0.91^{\text {cde }}\end{array}$ & $\begin{array}{l}20 \pm 0.54^{f} \\
25 \pm 0.73^{\text {ef }} \\
29 \pm 1.02^{\text {de }} \\
31 \pm 0.68^{\text {bcd }}\end{array}$ & $\begin{array}{l}11 \pm 0.34^{\mathrm{b}} \\
13 \pm 0.23^{\mathrm{ab}} \\
15 \pm 0.21^{\mathrm{a}} \\
15 \pm 0.45^{\mathrm{a}}\end{array}$ & $\begin{array}{l}61 \pm 1.02^{\mathrm{i}} \\
74 \pm 0.91^{\mathrm{gh}} \\
83 \pm 1.60^{\text {ef }} \\
88 \pm 0.98^{\mathrm{d}}\end{array}$ \\
\hline SM I & $\begin{array}{l}\text { Fresh } \\
30 \\
60 \\
90\end{array}$ & $\begin{array}{l}31 \pm 0.62^{\text {hi }} \\
36 \pm 1.04^{\text {fgh }} \\
40 \pm 0.84^{\text {defg }} \\
430.87^{\text {bcde }}\end{array}$ & $\begin{array}{l}25 \pm 0.80^{\text {ef }} \\
29 \pm 0.96^{\text {de }} \\
31 \pm 0.55^{\text {bcd }} \\
32 \pm 0.51^{\text {bc }}\end{array}$ & $\begin{array}{l}12 \pm 0.12^{\mathrm{b}} \\
13 \pm 0.34^{\mathrm{ab}} \\
15 \pm 0.55^{\mathrm{a}} \\
15 \pm 0.26^{\mathrm{a}}\end{array}$ & $\begin{array}{l}67 \pm 2.02^{\mathrm{hi}} \\
78 \pm 0.78^{\mathrm{fg}} \\
86 \pm 0.98^{\mathrm{de}} \\
90 \pm 1.44^{\mathrm{cd}}\end{array}$ \\
\hline SM II & $\begin{array}{l}\text { Fresh } \\
30 \\
60 \\
90 \\
\text { Fresh } \\
30 \\
60 \\
90\end{array}$ & $\begin{array}{l}33 \pm 1.02^{\mathrm{ghl}} \\
39 \pm 0.55^{\text {efg }} \\
42 \pm 0.65^{\mathrm{cde}} \\
45 \pm 0.73^{\mathrm{abc}} \\
38 \pm 0.61^{\mathrm{efg}} \\
43 \pm 0.82^{\mathrm{bcde}} \\
45 \pm 0.71^{\mathrm{abc}} \\
42 \pm 0.56^{\mathrm{cde}}\end{array}$ & $\begin{array}{l}27 \pm 0.65^{\mathrm{e}} \\
30 \pm 0.83^{\mathrm{d}} \\
32 \pm 0.90^{\mathrm{bc}} \\
34 \pm 1.04^{\mathrm{ab}} \\
31 \pm 0.63^{\mathrm{bcd}} \\
33 \pm 0.54^{\mathrm{b}} \\
35 \pm 0.34^{\mathrm{a}} \\
32 \pm 0.72^{\mathrm{bc}}\end{array}$ & $\begin{array}{l}12 \pm 0.29^{\mathrm{b}} \\
14 \pm 0.30^{\mathrm{ab}} \\
15 \pm 0.31^{\mathrm{a}} \\
15 \pm 0.19^{\mathrm{a}} \\
12 \pm 0.60^{\mathrm{b}} \\
14 \pm 0.22^{\mathrm{ab}} \\
15 \pm 0.41^{\mathrm{a}} \\
15 \pm 0.25^{\mathrm{a}}\end{array}$ & $\begin{array}{l}72 \pm 0.99^{\mathrm{h}} \\
83 \pm 0.87^{\mathrm{ef}} \\
89 \pm 1.46^{\mathrm{d}} \\
94 \pm 0.88^{\mathrm{bc}} \\
81 \pm 0.65^{\dagger} \\
90 \pm 1.02^{\mathrm{cd}} \\
95 \pm 1.30^{\mathrm{b}} \\
89 \pm 0.96^{\mathrm{d}}\end{array}$ \\
\hline DL I & $\begin{array}{l}\text { Fresh } \\
30 \\
60 \\
90\end{array}$ & $\begin{array}{l}30 \pm 0.96^{\mathrm{i}} \\
36 \pm 0.74^{\text {fgh }} \\
40 \pm 0.53^{\text {efg }} \\
42 \pm 1.10^{\text {cde }}\end{array}$ & $\begin{array}{l}28 \pm 0.66^{\mathrm{e}} \\
31 \pm 0.98^{\mathrm{bcd}} \\
32 \pm 0.81^{\mathrm{bc}} \\
33 \pm 1.08^{\mathrm{b}}\end{array}$ & $\begin{array}{l}12 \pm 0.22^{\mathrm{b}} \\
14 \pm 0.35^{\mathrm{ab}} \\
15 \pm 0.31^{\mathrm{a}} \\
15 \pm 0.55^{\mathrm{a}}\end{array}$ & $\begin{array}{l}70 \pm 0.94^{\mathrm{ghi}} \\
81 \pm 1.07^{f} \\
88 \pm 0.93^{\mathrm{d}} \\
90 \pm 2.01^{\mathrm{cd}}\end{array}$ \\
\hline DL II & $\begin{array}{l}\text { Fresh } \\
30 \\
60 \\
90\end{array}$ & $\begin{array}{l}34 \pm 0.58^{\text {ghi }} \\
39 \pm 1.08^{\text {efg }} \\
43 \pm 0.81^{\text {bcde }} \\
44 \pm 0.68^{\text {bcd }}\end{array}$ & $\begin{array}{l}30 \pm 0.55^{\mathrm{d}} \\
33 \pm 0.75^{\mathrm{b}} \\
34 \pm 0.79^{\mathrm{ab}} \\
35 \pm 0.53^{\mathrm{a}}\end{array}$ & $\begin{array}{l}12 \pm 0.18^{\mathrm{b}} \\
14 \pm 0.32^{\mathrm{ab}} \\
15 \pm 0.34^{\mathrm{a}} \\
15 \pm 0.21^{\mathrm{a}}\end{array}$ & $\begin{array}{l}76 \pm 0.84^{\mathrm{g}} \\
86 \pm 1.00^{\mathrm{de}} \\
92 \pm 0.82^{\mathrm{c}} \\
94 \pm 1.12^{\mathrm{bc}}\end{array}$ \\
\hline DL III & $\begin{array}{l}\text { Fresh } \\
30 \\
60 \\
90\end{array}$ & $\begin{array}{l}39 \pm 0.78^{\text {efg }} \\
42 \pm 1.02^{\text {cde }} \\
45 \pm 0.55^{\text {abc }} \\
47 \pm 0.69^{a}\end{array}$ & $\begin{array}{l}32 \pm 0.90^{\mathrm{bc}} \\
33 \pm 0.55^{\mathrm{b}} \\
34 \pm 0.45^{\mathrm{ab}} \\
35 \pm 1.02^{\mathrm{a}}\end{array}$ & $\begin{array}{l}12 \pm 0.09^{\mathrm{b}} \\
14 \pm 0.19^{\mathrm{ab}} \\
15 \pm 0.29^{\mathrm{a}} \\
15 \pm 0.34^{\mathrm{a}}\end{array}$ & $\begin{array}{l}83 \pm 0.91^{\text {ef }} \\
89 \pm 0.67^{d} \\
94 \pm 1.08^{b c} \\
97 \pm 1.30^{a}\end{array}$ \\
\hline PR I & $\begin{array}{l}\text { Fresh } \\
30 \\
60 \\
90\end{array}$ & $\begin{array}{l}31 \pm 0.91^{\text {hi }} \\
35 \pm 0.69^{\text {fghi }} \\
39 \pm 0.62^{\text {efg }} \\
43 \pm 0.56^{\text {bcde }}\end{array}$ & $\begin{array}{l}27 \pm 0.75^{\mathrm{e}} \\
30 \pm 0.67^{\mathrm{d}} \\
31 \pm 0.70^{\mathrm{bcd}} \\
32 \pm 0.88^{\mathrm{bc}}\end{array}$ & $\begin{array}{l}11 \pm 0.33^{\mathrm{b}} \\
14 \pm 0.29^{\mathrm{ab}} \\
15 \pm 0.36^{\mathrm{a}} \\
15 \pm 0.42^{\mathrm{a}}\end{array}$ & $\begin{array}{l}69 \pm 0.67^{\text {ghi }} \\
79 \pm 0.99^{\text {fg }} \\
84 \pm 1.06^{\mathrm{e}} \\
90 \pm 0.91^{\mathrm{cd}}\end{array}$ \\
\hline PR II & $\begin{array}{l}\text { Fresh } \\
30 \\
60 \\
90\end{array}$ & $\begin{array}{l}32 \pm 1.04^{\mathrm{hi}} \\
37 \pm 0.91^{\mathrm{efgh}} \\
42 \pm 0.83^{\mathrm{cde}} \\
45 \pm 0.76^{\mathrm{abc}}\end{array}$ & $\begin{array}{l}30 \pm 0.55^{\mathrm{d}} \\
33 \pm 0.81^{\mathrm{b}} \\
34 \pm 1.02^{\mathrm{ab}} \\
35 \pm 0.48^{\mathrm{a}}\end{array}$ & $\begin{array}{l}12 \pm 0.12^{\mathrm{b}} \\
140.43^{\mathrm{ab}} \\
15 \pm 0.29^{\mathrm{a}} \\
15 \pm 0.26^{\mathrm{a}}\end{array}$ & $\begin{array}{l}74 \pm 0.82^{\mathrm{gh}} \\
84 \pm 1.02^{\mathrm{e}} \\
91 \pm 0.77^{\mathrm{c}} \\
95 \pm 0.62^{\mathrm{b}}\end{array}$ \\
\hline PR III & $\begin{array}{l}\text { Fresh } \\
30 \\
60 \\
90\end{array}$ & $\begin{array}{l}39 \pm 0.55^{\text {etg }} \\
41 \pm 0.78^{\text {def }} \\
46 \pm 1.02^{\text {ab }} \\
41 \pm 0.82^{\text {def }}\end{array}$ & $\begin{array}{l}33 \pm 0.49^{\mathrm{b}} \\
34 \pm 0.55^{\mathrm{ab}} \\
35 \pm 0.89^{\mathrm{a}} \\
32 \pm 0.95^{\mathrm{bc}}\end{array}$ & $\begin{array}{l}12 \pm 0.22^{\mathrm{b}} \\
14 \pm 0.21^{\mathrm{ab}} \\
15 \pm 0.43^{\mathrm{a}} \\
15 \pm 0.55^{\mathrm{a}}\end{array}$ & $\begin{array}{l}84 \pm 0.76^{\mathrm{e}} \\
89 \pm 0.84^{\mathrm{d}} \\
96 \pm 1.06^{\mathrm{ab}} \\
88 \pm 0.98^{\mathrm{d}}\end{array}$ \\
\hline
\end{tabular}

Note: Mean \pm (St. Dev.) having different alphabets within each column are significantly different $(p \leq 0.05)$.

\section{Conclusion}

Taking into account all the results obtained, it can be concluded that fat replacers particularly Simplesse®100, Dairy LoTM and Prolo®11 at $0.9 \%$ could be effectively used for the enhancement of physicochemical, firmness, microstructure and sensory characteristics of LFEC. Replacement of fat with FR resulted in significant improvement of moisture, and salt retention compared to $\mathrm{C}$ cheese. SM and PR
$(0.9 \%)$ improved the structure of low-fat buffalo Edam cheese in less than 2 months. Whereas, it took DL $(0.9 \%) 3$ months to start the improvement. Hence, among the fat replacers, it was noticed that PR and SM had the largest impact on structure and protein enhanced with increased moisture content and better sensorial properties. In further work, different concentrations and combinations of these and some other fat replacers should be explored for better results. 


\section{References}

Akkerman, M., Kristensen, L.S., Jespersen, L., Ryssel, M.B., Mackie, A., Larsen, N.N., Andersen, U., Nørgaard, M.K., Løkke, M.M., Møller, J.R., \& Mielby, L.A. (2017). Interaction between sodium chloride and texture in semi-hard Danish cheese as affected by brining time, dl-starter culture, chymosin type and cheese ripening. International Dairy Journal, 70, 3445.

AOAC. (2000). Official method of analysis. 17th Ed. Washington, DC: AOAC International.

Aryana, K.J., \& Haque, Z.U. (2001). Effect of commercial fat replacers on the microstructure of low-fat Cheddar cheese. International journal of food science \& technology, 36,169-177.

Clark, S., Costello, M., Drake, M., \& Bodyfelt, F. (2009). The Sensory Evaluation of Dairy Products. New York: Springer Science \& Business Media, pp. 167-191.

Costa, N.E., Hannon, J.A., Guinee, T.P., Auty, M.A.E., McSweeney, P.L.H., \& Beresford, T.P. (2010). Effect of exopolysaccharide produced by isogenic strains of Lactococcus lactis on half-fat Cheddar cheese. Journal of dairy science, 93, 34693486.

De-Magistris, T., \& Lopéz-Galán, B. (2016). Consumers' willingness to pay for nutritional claims fighting the obesity epidemic: the case of reduced-fat and low salt cheese in Spain. Public health, 135, 8390.

Diamantino, V.R., Beraldo, F.A., Sunakozawa, T.N., \& Penna, A.L.B. (2014). Effect of octenyl succinylated waxy starch as a fat mimetic on texture, microstructure and physicochemical properties of Minas fresh cheese. LWT-Food Science and Technology, 56, 356-362.

Drake, M.A., Boylston, T.D., \& Swanson, B.G. (1996). Fat Mimetics in Low-Fat Cheddar Cheese. Journal of Food Science, 61,1267-1271.

El-Aidie, S.A.A., El-Dieb, S.M., El-Nawawy, M., Emara, E., \& Sobhy, H. (2017). Nutraceutical Food Based on Cereal and Probiotic Fermented Milk. International Journal of Dairy Science, 12, 377384.

El-Aidie, S.A.M. (2018 a). A Review on Chitosan: Ecofriendly Multiple Potential Applications in the Food Industry. International Journal of Advancement in Life Sciences Research, pp.1-14.

El-Aidie, S.A.M. (2018 b). The Healthiness of Commercial Butter in Malaysia: Evaluation of the Physicochemical and Microbial Quality. International Journal of Advancement in Life Sciences Research, pp.1-7.

El-Garhi, H.E.M., El-Aidie, S.A., Rashid, N.A., \& Hayee, Z.A. (2018). Quality improvement of spreadable processed cheese made from ultrafiltered milk retentates using commercial starter cultures. Food Science and Technology International, 24(6), 465-475
El Soda, M. (2014). Production of low-fat cheddar cheese made using exopolysaccharide-producing cultures and selected ripening cultures. Advances in Microbiology, 4, 986.

Fox PF. (1993). Cheese: an overview. In Cheese: chemistry, physics and microbiology (pp. 1-36). Springer, Boston, MA.

Govindasamy-Lucey, S., Lu, Y., Jaeggi, J.J., Johnson, M.E., \& Lucey, J.A. (2010). Impact of camel chymosin on the texture and sensory properties of low-fat cheddar cheese. Australian Journal of Dairy Technology, 65(3),139.

IDF. (2006). Determination of the nitrogen content and calculation of crude protein. Int Dairy Federation, Brussels, Belgium

Johnson, M.E., Kapoor, R., McMahon, D.J., McCoy, D.R., \& Narasimmon, R.G. (2009). Reduction of sodium and fat levels in natural and processed cheeses: scientific and technological aspects. Comprehensive Reviews in Food Science and Food Safety, 8,252-268.

Jooyandeh, H., Goudarzi, M., Rostamabadi, H., \& Hojjati, M. (2017). Effect of Persian and almond gums as fat replacers on the physicochemical, rheological, and microstructural attributes of low-fat Iranian White cheese. Food science and nutrition, 5, 669-677.

Junyusen, T., Ngampang, N., Sangmuang, A., Suthada, S., \& Chatchavanthatri, N. (2017). The Effects of Inulin on The Textural, Thermal, and Microstructural Properties of Reduced-Fat Cheese. Suranaree Journal of Science and Technology, 24, 23-30.

Karaman, A. D., \& Akalın, A.S. (2013). Improving quality characteristics of reduced and low fat Turkish white cheeses using homogenized cream. LWT-Food Science and Technology, 50, 503-510.

Katsiari, M.C., \& Voutsinas, L.P. (1994). Manufacture of low-fat Feta cheese. Food Chemistry, 49, 53-60.

Kavas, G., Oysun, G., Kinik, O. \& Uysal, H. (2004). Effect of some fat replacers on chemical, physical and sensory attributes of low-fat white pickled cheese. Food chemistry, 88, 381-388.

Koca, N., \& Metin, M. (2004). Textural, melting and sensory properties of low-fat fresh kashar cheeses produced by using fat replacers. International Dairy Journal, 14, 365-373.

Kuchroo, C.N., \& Fox, P. F. (1982). Soluble nitrogen in Cheddar cheese: comparison of extraction procedures. Milchwissenschaft, 37, 331-335.

Kucukoner, E. (1996). Effect of commercial fat replacers on the physico-chemical properties and rheology of low-fat Cheddar cheese (Doctoral dissertation, PhD thesis Mississippi State University, MS State, USA).

Kumar, P., \& Upadhyay, K.G. (1998). Biochemical, textural and sensory changes during ripening of buffalo milk Cheddar cheese manufactured by half- 
whey salting technique. Indian journal of dairy science, 51, 226-232.

Lee, M.R., Johnson, M.E., \& Lucey, J.A. (2005). Impact of modifications in acid development on the insoluble calcium content and rheological properties of Cheddar cheese. Journal of dairy science, 88, 3798-3809.

Marshal, R.T. (1993). Standard methods for determination of dairy Products. 16th Ed. American Public Health Association. Washington, D.C

Madadlou, A., Khosroshahi, A., \& Mousavi, M.E. (2005). Rheology, microstructure, and functionality of low-fat Iranian white cheese made with different concentrations of rennet. Journal of Dairy Science, $88,3052-3062$.

McCarthy, C.M., Wilkinson, M.G., \& Guinee, T.P. (2017). Effect of coagulant type and level on the properties of half-salt, half-fat Cheddar cheese made with or without adjunct starter: Improving texture and functionality. International Dairy Journal, 75, 30-40.

McMahon, D.J., Alleyne, M.C., Fife, R.L., \& Oberg, C.J. (1996). Use of Fat Replacers in Low Fat Mozzarella Cheese1. Journal of Dairy Science, 79,1911-1921.

Mistry, V.V., \& Anderson, D.L. (1993). Composition and microstructure of commercial full-fat and low-fat cheeses. Food structure, 12,13.

Murtaza, M.A., Huma, N., Sameen, A., Murtaza, M.S., Mahmood, S., Mueen-ud-Din, G., \& Meraj, A. (2014). Texture, flavor, and sensory quality of buffalo milk Cheddar cheese as influenced by reducing sodium salt content. Journal of dairy science, 97, 6700-6707.

Murtaza, M.S., Sameen, A., Huma, N., \& Hussain, F. (2017). Influence of Hydrocolloid Gums on Textural, Functional and Sensory Properties of Low-Fat Cheddar Cheese from Buffalo Milk. Pakistan Journal of Zoology, 49, 27-27.

Nateghi, L., Roohinejad, S., Totosaus, A., Mirhosseini, H., Shuhaimi, M., Meimandipour, A., Omidizadeh, A., \& Abd-Manap, M.Y. (2012). Optimization of textural properties and formulation of reduced fat Cheddar cheeses containing fat replacers. Journal of Food, Agriculture and Environment, 10, 46-54.

Oliveira, N.M., Dourado, F.Q., Peres, A.M., Silva, M.V., Maia, J.M., \& Teixeira, J.A. (2011). Effect of guar gum on the physicochemical, thermal, rheological and textural properties of green edam cheese. Food and bioprocess technology, 4,14141421.

Palatnik, D.R., Aldrete Herrera, P., Rinaldoni, A.N., Ortiz Basurto, R.I., \& Campderrós, M.E. (2017). Development of reduced-fat cheeses with the addition of Agave fructans. International Journal of Dairy Technology, 70, 212-219.

Romeih, E.A., Michaelidou, A., Biliaderis, C.G., \& Zerfiridis, G.K. (2002). Low-fat white-brined cheese made from bovine milk and two commercial fat mimetics: chemical, physical and sensory attributes. International Dairy Journal, 12, 525-540.

Sahan, N., Yasar, K., Hayaloglu, A.A., Karaca, O.B., \& Kaya, A. (2008). Influence of fat replacers on chemical composition, proteolysis, texture profiles, meltability and sensory properties of low-fat Kashar cheese. Journal of Dairy Research, 75,1-7.

Sandrou, D. K., \& Arvanitoyannis, I.S. (2000). LowFat/Calorie Foods: Current State and Perspectives. Critical Reviews in Food Science and Nutrition, 40, 427-447.

Sheehan, J.J., Huppertz, T., Hayes, M.G., Kelly, A.L., Beresford, T.P., \& Guinee, T.P. (2005). High pressure treatment of reduced-fat Mozzarella cheese: Effects on functional and rheological properties. Innovative Food Science and Emerging Technologies, 6, 73-81.

Sheibani, A., Ayyash, M.M., Vasiljevic, T., \& Mishra, V.K. (2017). Texture and microstructure of reducedsalt Cheddar cheese as affected by process modifications. International. Food Research Journal, 24, 643-650.

Søndergaard, L., Ryssel, M., Svendsen, C., Høier, E., Andersen, U., Hammershøj, M., Møller J.R., Arneborg, N., \& Jespersen, L. (2015). Impact of $\mathrm{NaCl}$ reduction in Danish semi-hard Samsoe cheeses on proliferation and autolysis of DL-starter cultures. International journal of food microbiology, 213, 59-70.

Soodam, K., Ong, L., Powell, I.B., Kentish, S.E., \& Gras, S.L. (2015). Effect of calcium chloride addition and draining $\mathrm{pH}$ on the microstructure and texture of full fat Cheddar cheese during ripening. Food Chemistry, 181, 111-118. 